\title{
Primary intracystic squamous cell carcinoma of breast
}

\section{Memenin primer intrakistik skuamöz hücreli karsinomu}

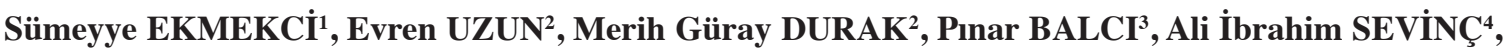 \\ Tülay CANDA ${ }^{2}$
}

${ }^{1}$ Tepecik Ĕ̆itim ve Araștırma Hastanesi Patoloji Bölümü, İzmir, Türkiye

${ }^{2}$ Dokuz Eylül Üniversitesi Tıp Fakültesi Patoloji Anabilim Dalı, İzmir, Türkiye

${ }^{3}$ Dokuz Eylül Üniversitesi Tıp Fakültesi Radyoloji Anabilim Dalı, İzmir, Türkiye

${ }^{4}$ Dokuz, Eylül Üniversitesi Tıp Fakültesi Genel Cerrahi Anabilim Dalı, İzmir, Türkiye

\begin{abstract}
Primary squamous cell carcinoma (SCC) of the breast accounts for less than $0.04 \%$ of all breast carcinomas. Ultrasonographic imaging of a 41-year-old female showed a lesion compatible with complex cyst with a symmetric thick-walled septations in the right breast, with a dimension of $8 x 7.5 \mathrm{~cm}$. Histopathologic examination showed nests of squamous neoplastic cells with occasional intercellular bridges and atypical mitotic figures infiltrating the breast parenchyma, as well as dysplastic squamous cells lining the cyst wall. Targeted treatment modalities need to be developed to achieve beter clinical outcome in these tumors, therefore more extensive series of studies are required.
\end{abstract}

Keywords: breast, breast carcinoma, intracystic squamous cell carcinoma

$\ddot{0} \mathbf{Z}$

Memenin primer skuamöz hücreli karsinomu tüm meme karsinomlarının \%0,04'ten azını oluşturur. Kırk bir yaşında kadın hastanın să̆ memesinde ultrasonografik görüntülemesinde, 8x7,5 cm boyutlarında, asimetrik, kalın duvarlı, septasyonlar içeren kompleks kist ile uyumlu lezyon izlenmiştir. Histopatolojik incelemede kist duvarını döşeyen displastik skuamöz hücreler yanı sıra meme parenkimini infiltre eden, gruplar oluşturmuş, yer yer intersellüler köprüler içeren skuamoid görünümlü neoplastik hücreler ile arada atipik mitotik figürler izlenmiştir. Memenin SHK'ları da dahil metaplastik karsinomlarında daha iyi klinik gidişe ulaşabilmek için hedefe yönelik tedavi modelleri geliştirilmesi gerekmektedir. Bu nedenle de bu tümörlerde daha geniş serilerde çalışmalara gereksinim duyulmaktadır.

Anahtar kelimeler: meme, meme karsinomu, intrakistik skuamöz hücreli karsinom

Alındığı tarih: 05.07 .2017
Kabul tarihi: 12.07 .2017

Yazışma adresi: Uzm. Dr. Sümeyye Ekmekci, Tepecik Eğitim ve Araştırma Hastanesi Patoloji Kliniği, İzmir - Türkiye e-mail: ekmekcisumeyye@gmail.com **Bu makale 24. Ulusal Patoloji Kongresi (Trabzon)'nde sunulmuştur.

\section{INTRODUCTION}

Breast cancer is the most common malignancy in women and the second leading cause of death. Primary squamous cell carcinoma (SCC) of the breast accounts for less than $0.04 \%$ of all breast carcinomas ${ }^{(1)}$. Similar to other metaplastic carcinomas of the breast, the prognosis of SCC is worse than invasive ductal and lobular carcinomas of the breast ${ }^{(2)}$.

\section{CASE REPORT}

Ultrasonographic imaging of a 41-year-old female showed a lesion compatible with a $8 \times 7.5 \mathrm{~cm}$ complex cyst of the right breast containing symmetric thickwalled septations. Fine-needle aspiration biopsy revealed a malignant tumor. The excision material consisted of irregular tissue fragments reminiscent of cyst wall, the largest being $6 \mathrm{~cm}$ in diameter (Figure 


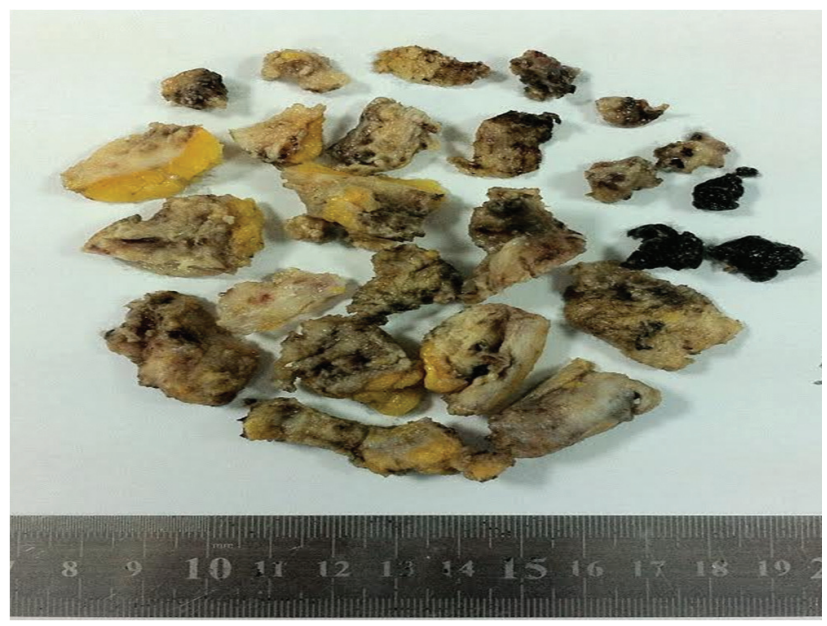

Figure 1. Gross specimen consisting of tissue fragments representing the cyst wall.

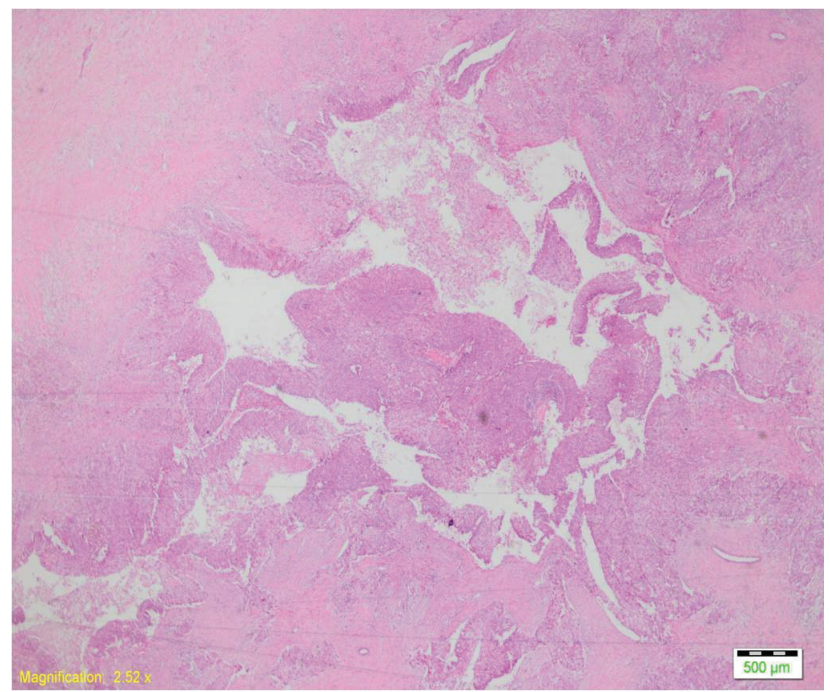

Figure 2a. Histologically, squamoid tumor cells lining the cystic space are seen $(\mathrm{H} \& \mathrm{E}, \mathrm{x} 40)$.

1). Histopathologic examination showed nests of squamous neoplastic cells with occasional intercellular bridges and atypical mitotic figures infiltrating the breast parenchyma, as well as dysplastic squamous cells lining the cyst wall (Figure 2a-b). These cells were diffusely immunoreactive for p63 (Figure 3). No lymphovascular invasion was detected. Simultaneously performed cyst aspiration fluid showed similar clusters of atypical cells (Figure 4). Immunohistochemically, tumor cells were negatively stained for estrogen and progesterone receptors.

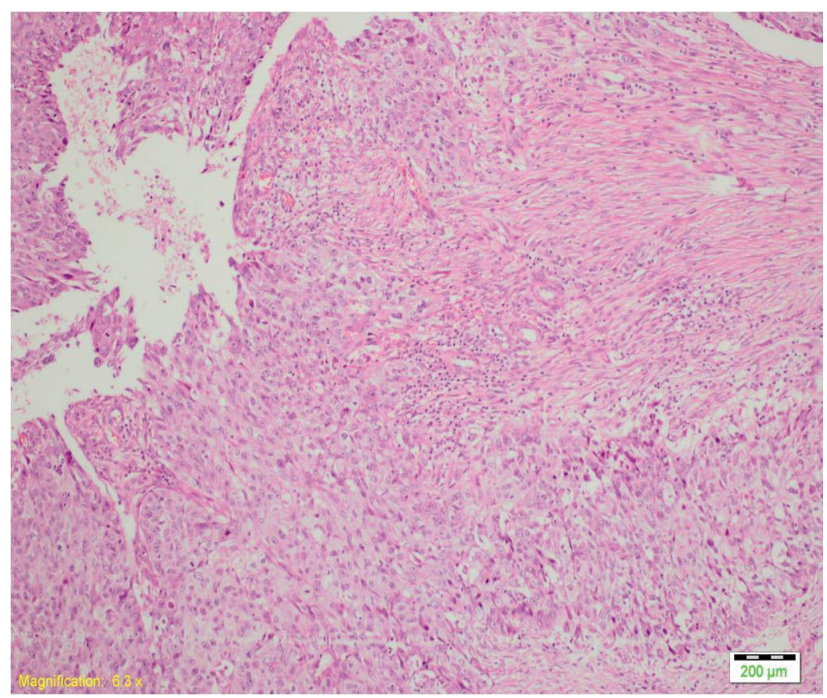

Figure 2b. Nests of pleomorphic squamoid neoplastic cells with large eosinophilic cytoplasm are prominent (H\&E, x100).

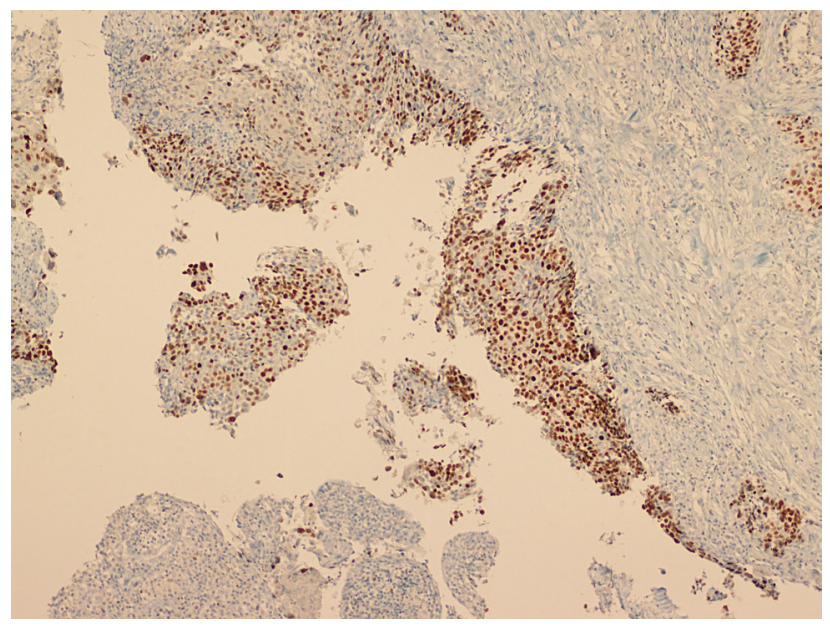

Figure 3. Immunohistochemically, tumor cells showed diffuse nuclear p63 staining (x100).

HER2 was also negative. Ki-67 proliferative index of the tumor was $40 \%$. The patient was diagnosed as primary intracystic SCC of the breast. Subsequently, simple mastectomy and sentinel lymph node biopsy were performed. Residual tumor with similar morphology was present in the specimen, around the cavity, that was $17 \times 10 \mathrm{~mm}$ in size. The tumoral cells also invaded the deep dermis. No metastasis was detected in the sentinel lymph node. The patient received chemotherapy and radiotherapy, and she is well without disease at postoperative $28^{\text {th }}$ month. 


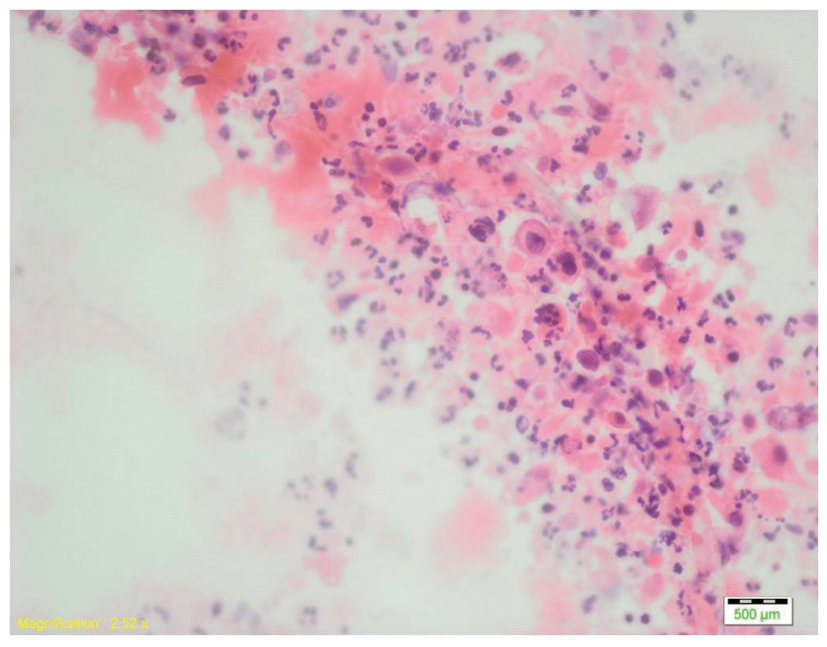

Figure 4. Cyst aspiration fluid of the tumor showed similar clusters of atypical squamoid cells $(\mathrm{x} 400)$.

\section{CONCLUSION}

Metaplastic carcinoma of the breast include lowgrade adenosquamous carcinoma, fibromatosis-like metaplastic carcinoma, SCC, spindle cell carcinoma, and carcinoma with mesenchymal differentiation, according to WHO classification of tumors of the breast ${ }^{(3)}$. Squamous differentiation should be more than $90 \%$ of the tumor in order to diagnose as primary SCC of the breast. The most important differential diagnosis is metastatic SCC from other sites, especially skin ${ }^{(4)}$. Precise clinical history and careful examination of the specimen for the presence of in situ carcinoma is helpful in these cases. Some cases may develop from benign tumors, such as adenofibroma, cyst, chronic inflammation or abscess ${ }^{(1)}$. It is hypothesized that, squamous metaplasia that occurs in these benign tumors may provide basis for the development of a malignant tumor.

Different morphological patterns may be prominent in these tumors, such as keratinization, acantholysis, cystic, papillary changes, or spindle or clear cell morphology ${ }^{(5)}$. Primary SCCs of the breast are generally cystic lesions that may reach large sizes. The majority are triple-negative with agressive beha- viour and poor prognosis. Distant metastasis is observed in $30 \%$ of the cases.

Treatment modalities and effects are not clear due to their rare ocurrence and limited case series, and may include surgery, chemotherapy and radiotherapy similar to other breast cancers. Hormonal therapy is not a treatment option, since majority of the cases are triple-negative tumors.

To summarize, primary SCC of the breast should be diagnosed after exclusion of metastasis. It should be also kept in mind that metaplastic benign squamous cells may be present in other necrotizing and inflammatory conditions, such as cystic lesions, fatty necrosis, intraductal papilloma and mastitis. Targeted treatment modalities need to be developed to achieve beter clinical outcomes in these tumors, therefore larger series of studies should be performed.

Conflict of Interest: No conflict of interest was declared by the authors.

Financial Disclosure: The authors declared that this study has received no financial support.

\section{REFERENCES}

1. Accurso A, Pettinato G, Ciancia G, Bellevicine C, Riccardi A, Rocco N. Pure primary squamous cell carcinoma of the breast presenting as an intracystic tumor. Breast $\mathrm{J}$. 2012;18(6):608-9.

https://doi.org/10.1111/tbj.12017

2. Badge SA, Gangane NM, Shivkumar VB, Sharma SM. Primary squamous cell carcinoma of the breast. Int J Appl Basic Med Res. 2014;4(1):53-5. https://doi.org/10.4103/2229-516X.125697

3. Lakhani SR, Ellise IO, Schnitt SJ, Tan PH, van de Vijver MJ. editors. WHO classification of Tumors of the breast. $4^{\text {th }}$ edition. Lyon, France: IARC; 2012. p.85-7.

4. Bhosale SJ, Kshirsagar AY, Deshmukh SJ, Jagtap SV, Langade YB. Squamous cell carcinoma of the breast. Am J Case Rep. 2013;14:188-90. https://doi.org/10.12659/AJCR.883934

5. Nayak A, Wu Y, Gilcrease MZ. Primary squamous cell carcinoma of the breast: predictors of locoregional recurrence and overall survival. Am J Surg Pathol. 2013;37(6):867-73. https://doi.org/10.1097/PAS.0b013e3182877569 